\title{
AN INTEGRATED STUDY OF LANDSAT ETM AND CARTOSAT DEM DATA IN IDENTIFICATION OF BANDED IRON FORMATIONS (BIFs) ASSOCIATED WITH SULPHIDE MINERALIZATION
}

\author{
Chandrashekharappa AGASNALLI ${ }^{1)}$, M. S. DEEPAK ${ }^{1)}$ *, \\ T. K. LAKKUNDI ${ }^{2)}$ and V. G. Ajey KUMAR ${ }^{3)}$ \\ 1) Department of Civil Engineering, BMS Institute of Technology and Management, Yelahanka, Bengaluru, India \\ 2) Department of Geology, School of Earth Sciences, Central University of Karnataka, Kalaburagi, India \\ 3) Sri Venkateshwara College of Engineering, Bangalore India \\ *Corresponding author's e-mail: deepakms143@gmail.com
}

\section{ARTICLE INFO}

Article history:

Received 12 July 2021

Accepted 26 November 2021

Available online 15 December 2021

\section{Keywords:}

Sulphide mineralisation

Archaean

BIFs

Remote Sensing

GIS

Dharwar Craton

Gadag Schist Belt and Gold

\begin{abstract}
This paper deals with the identification of BIFs and associated sulphide mineralisation. An integrated approach, including the use of Landsat ETM-plus and Cartosat DEM data, GIS analysis, and geological data, is adopted for this purpose in the Nagavi area of Gadag Schist Belt (GSB), India. This integrated approach has enabled in identifying BIFs and structures. Band-7 of the ETMplus sensor of Landsat-7 is used to identify BIFs and Band-5 for lineaments and shear zones. As a result of this study, the presence of gold mineralisation in sheared zones is noticed. BIFs are the economically prominent litho-units in the GSB hosting high-grade iron ore deposits along with sulphide mineralised shear zones. The strata bound ore is hosted primarily by BIF, consisting of chlorite, alternating chert and magnetite, sulphides and carbonate bands of a millimetre to centimetre scale.
\end{abstract}

\section{INTRODUCTION}

The Dharwar Craton in India is host to many of the country's mineral resources, including the famous Hutti, Kolar, Gadag goldfields etc. This Craton is divided into the western and eastern blocks based on the nature and abundance of greenstone belts and the age of the gneissic basement rocks (Naqvi and Rogers, 1987; Naqvi, 2005). The Western Dharwar Craton (WDC) and Eastern Dharwar Craton (EDC) are considered to have different evolutionary histories and metallogenic characteristics (Rajamani et al., 1985; Naqvi and Rana Prathap, 2007). In addition, the Craton contains several Archaean greenstone belts, including the well-known Kolar Schist Belt, Hungund-Kushtagi Schist Belt, Sandur Schist Belt, Gadag Chitradurga Schist Belt and Dharwar-Shimoga Schist Belt. The development of the auriferous Gadag Schist Belt in the 1990s has assisted in a greater understanding of geology and gold mineralisation. It is composed dominantly of metabasalt in the western half of the belt and sediments in the eastern half.

BIF hosted Sulphide mineralisation in the Nagavi area, which forms the northern part of the Central Zone of the Gadag Schist Belt (Beeraiah et al., 2001 and Sawkar, 2010). Hence, it warrants a detailed study of the geochemistry of Banded Iron Formations of the Nagavi area. Hence, this study concentrates on the identification BIFs, associated sulphide mineralisation and the concentration of gold in the Nagavi area, which have been reported to be important carriers of gold. Previously, Ciampalini et al. (2013a), Ciampalini et al. (2013b), Feizi and Mansouri (2013), Mao et al. (2019) etc., have employed remote sensing techniques for the identification of BIFs in similar geological settings. Similarly, Abdullah et al. (2013) and Mandeng et al. (2018) have used remote sensing data for identifying structures. The prespectives of this study are, a) dentification of BIFs; b) identification of lineaments and shear zones; c) analysing the gold concentration at the seclected zone of interest.

\section{DESCRIPTION OF THE STUDY AREA 2.1. 1 LOCATION AND ACCESSIBILITY}

The Nagavi area is a part of the Gadag Schist Belt, and it is located in the northern part of the Gadag Schist Belt. The area is near Gadag town of Gadag taluk and about $6 \mathrm{~km}$ away from the district headquarter, Gadag, in northern Karnataka. The study area is a part of the Survey of India topo sheet numbered $48 \mathrm{M} / 11$ of 1:50000 scale and is bound by longitudes from $75035^{\prime} 21.15^{\prime \prime}$ to $75038^{\prime} 13.20^{\prime \prime} \mathrm{E}$ and latitudes from $15020^{\prime} 25.14^{\prime \prime}$ to $15024^{\prime} 9.65^{\prime \prime} \mathrm{N}$. It is spread over an area of 13 sq. km. 


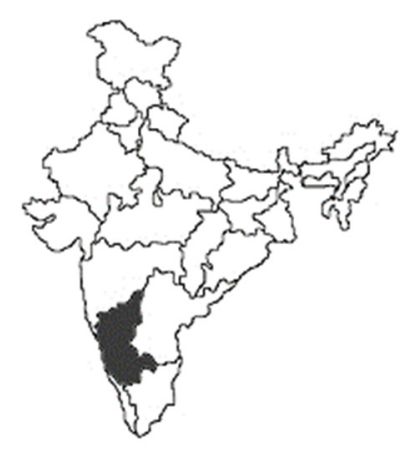

a) Country- INDIA

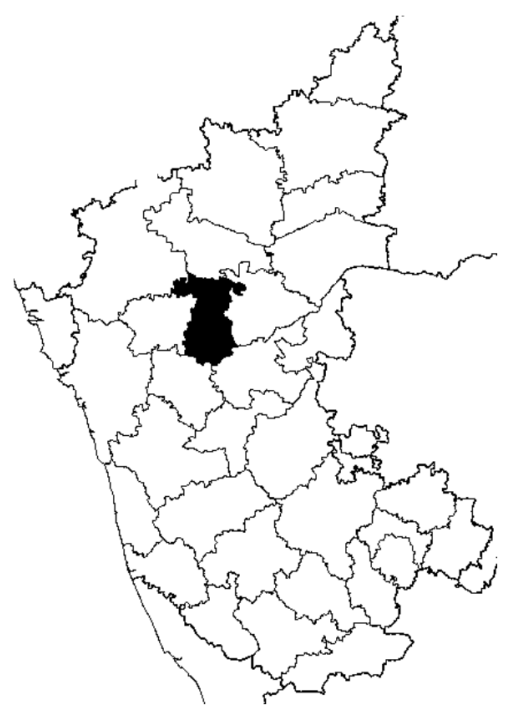

b) State- KARNATAKA

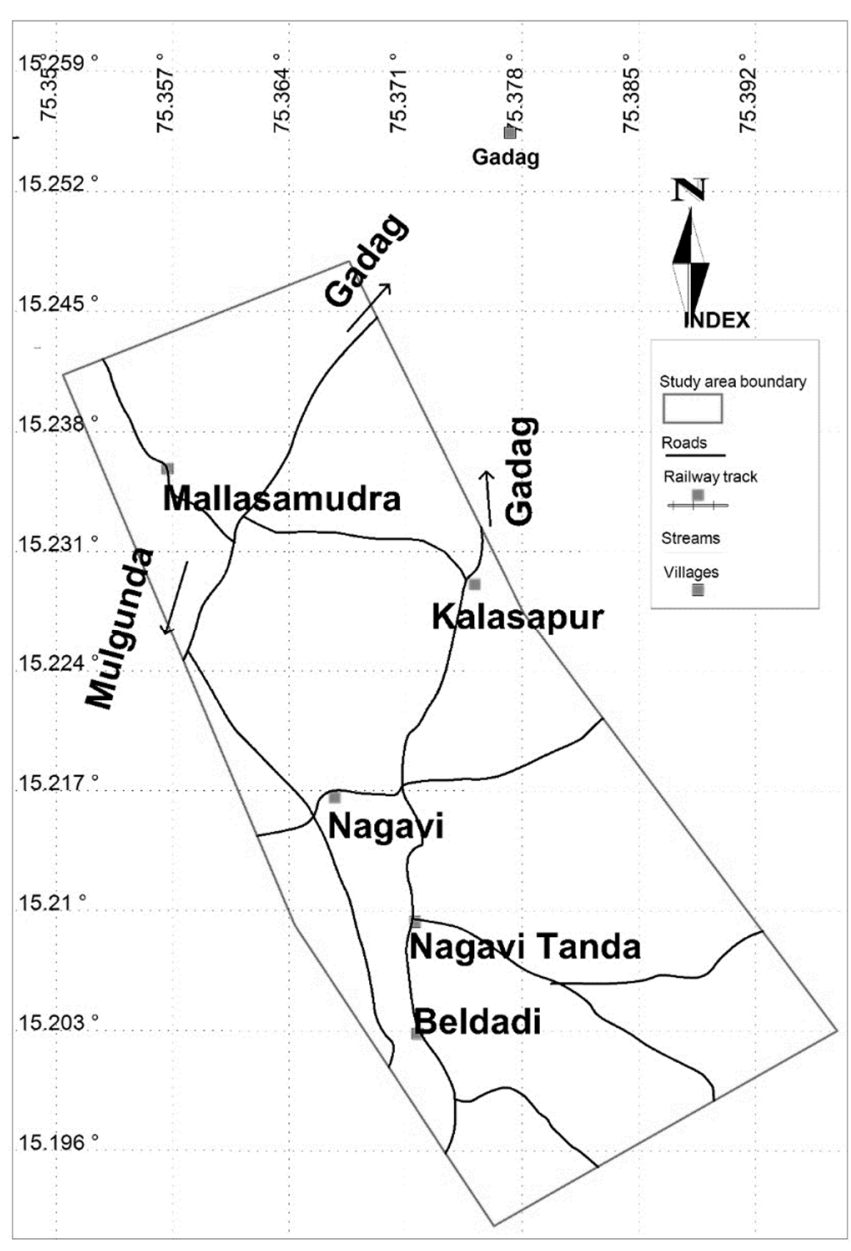

c) Study Zone-Area- GADAG- NAGAVI

Fig. 1 Location map of the study area, Nagavi (Google Images).

The National Highway towards the southwest connecting with Mulugunda city and another National Highway towards the west leads to Hubli-Dharwar city and good tar roads towards Shirhatti taluk in the south of Gadag city (Fig. 1). The Gadag district headquarters is about $350 \mathrm{~km}$ by road towards the northwest of Bangalore and is well connected to all the neighbouring areas by a good network of all-weather roads.

\subsection{LAND USE AND LAND COVER}

The Land Use (LU) and Land Cover (LC) map for the study area has been prepared using the Landsat digital data, and the same has been verified employing ground truth data. The LU and LC classification has been carried out using the ERDAS Imagine software. The LU pattern indicates that the vast majority of the area is used for agriculture, followed by a built-up area under plantations and vegetables in decreasing order of abundance (Fig. 2). Land with scrub represents the natural land cover in the area.

\subsection{TOPOGRAPHY}

For studying topography and topographical features in the Nagavi area, the Cartosat DEM has been used. The DEM data is used to generate elevation contours, and the resultant contours have been used to generate the slope map. No significant variation in the elevation is seen in the area as the minimum and maximum elevation are $700 \mathrm{~m}$ and $790 \mathrm{~m}$, respectively (Fig. 3), with the higher-elevation regions restricted to the central part of the study area. These higherelevation areas form isolated hillocks. Thus, the central regions represent higher slopes ranging from about 13 to 22 degrees (Fig. 4). Almost flat regions with gentle slopes represent areas on both sides of the hillocks.

\subsection{GEOLOGY OF NAGAVI AREA}

Regional geology includes different lithologies viz. gneisses, schists, amphibolites, basalts, Banded Iron Formations (BIFs) and quartz veins (Fig. 5). In the study area around Nagavi, metabasalts, BIFs, pyritiferous metabasalts, schists, shale, quartz veins 


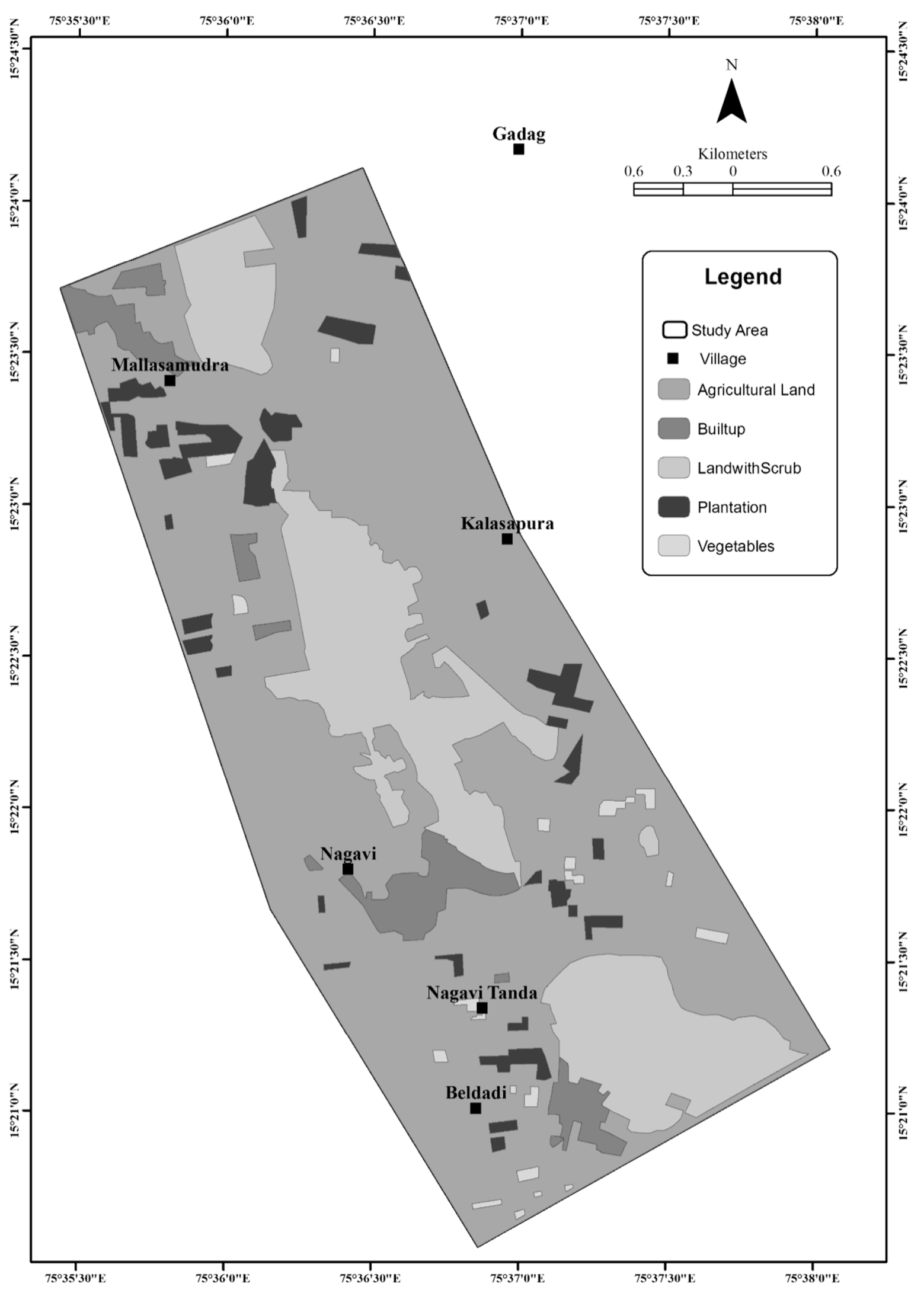

Fig. 2 Land Use and Land Cover pattern in the study area. 


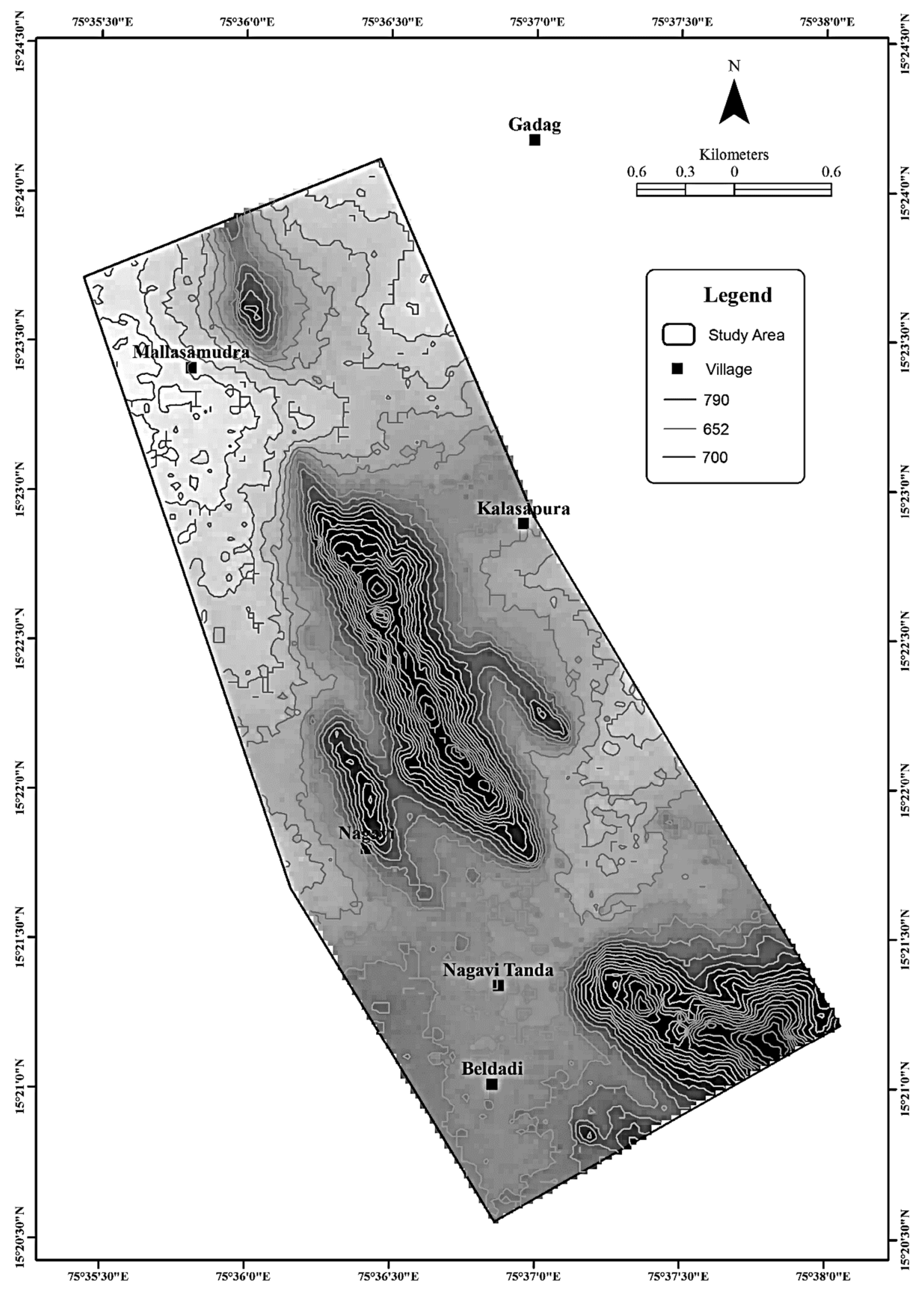

Fig. 3 Elevation distribution in the study area. 


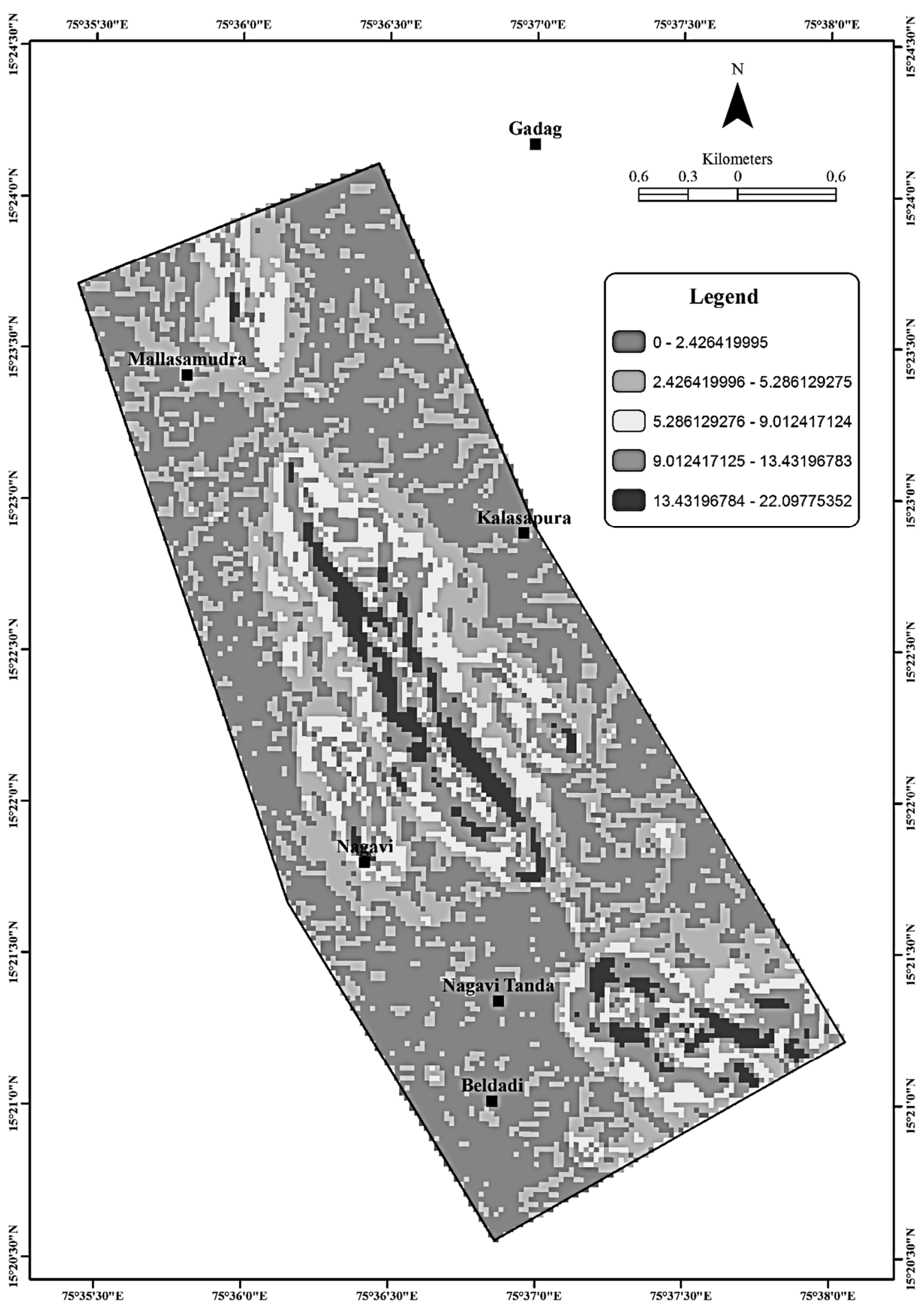

Fig. 4 Slope map of the study area. 


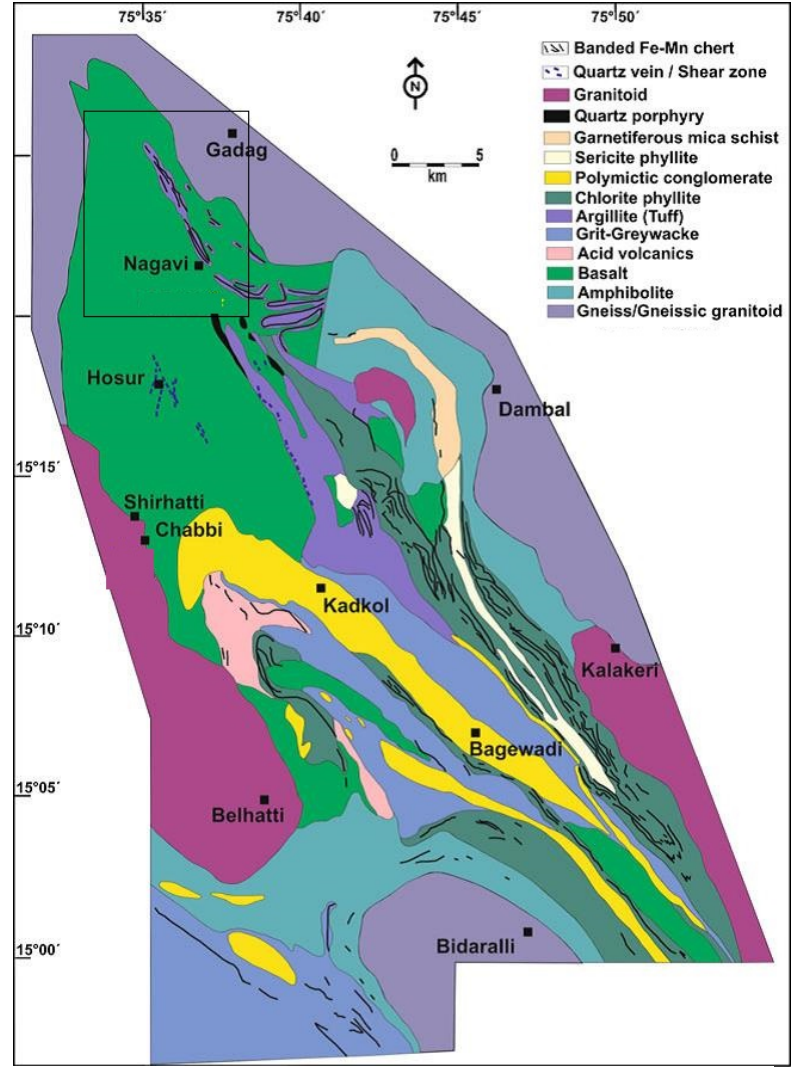

Fig. 5 Regional geological setup (Ramachandran et al., 2001).

and auriferous sheared quartz veins are identified by field investigations (Fig. 6). The BIFs occur as dissected bodies occupying the ridge part of the hillock, and their thickness varies from 1.5 to $22 \mathrm{~m}$. These BIFs extend to a length of more than 5 kilometers within the study area. Floats of BIFs occupy areas surrounding the ridge portion of the hillocks. These BIFs exhibit noticeable banding with alternate layers of acceptable to medium-grained magnetite/hematite, chert and auriferous sheared zones (Fig. 7). This compositional layering is usually expressed on several outcrop scales, from sub-millimetre-scale to feet-scale bands. In BIFs, hematite and magnetite lead the iron-rich layers, often accompanied by other metal oxides and sulphides such as pyrite and carbonates. The varying amounts of carbonate mineral phases, such as calcite and siderite, may be present in iron-rich and chert-rich layers. At some places, layers of silica may be jasperiferous. Thick inter-beds of shale are also associated with the BIF. Metabasalts occur on both sides of the hillocks, cut across by quartz veins. They are dark green, medium to fine-grained, compact rocks. Pyritiferous metabasalt occur near Mallasamudra village (Fig. 8). Greyish green medium-grained chlorite schist occurs in an old working pit near Mallasamudra village. Schistocity is observed to be well developed in these. Reddish-brown coloured shale is observed near Nagavi and Mallasamudra village. It forms skinny bands with medium to fine grain. It occurs as alternating bands within BIFs and quartz veins. Sugary

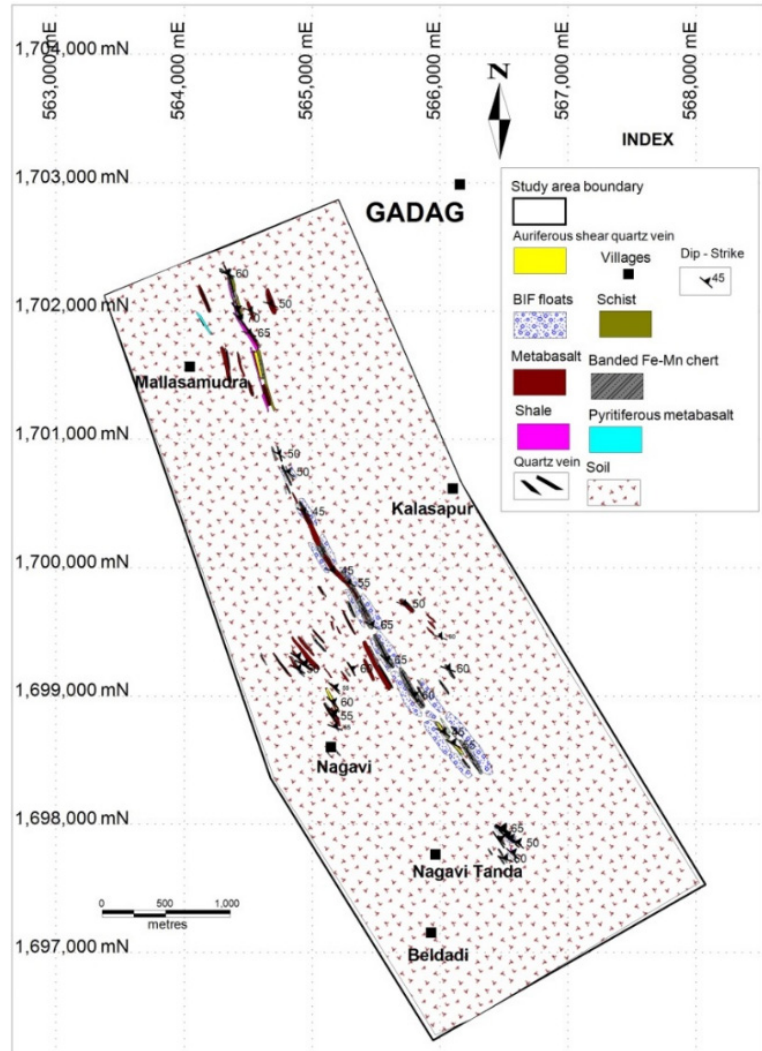

Fig. 6 Geology of the Nagavi area.

white quartz occurs on top of the ridge, and thin quartz veins are observed within the BIFs and metabasalts. The auriferous sheared quartz vein zones occur within the contact of BIFs at some places.

\section{MATERIALS AND METHODS}

Since this study involved an integrated approach, remote sensing data in the form of Landsat-7 ETM+ digital data is used to identify and delineate BIFs and LU/LC mapping. For generating contours, preparing slope maps, and identifying lineaments and shear zones, the Cartosat DEM data is used. ERDAS Imagine, ArcGIS and MapInfo GIS software are used for image processing and the generation of thematic maps. For ground truth verification, confirmation, geological mapping and sample collection, extensive field investigations are carried out. Basic geological field instruments like the Brunton Compass, GPS receiver (Garmin Map 62S model), field lens, hammer and toposheets published by Survey of India are used. Field data like litho-contacts, rock exposure, location coordinates, trends and descriptions are recorded during geological traverses. Fresh outcrop samples from the representative lithounits are selected from the in-situ outcrops during geological mapping. Few rock-chip samples are collected during geological mapping for petrographic studies and for analysing gold concentration. The GTA-AAS (Graphite Tube Atomization in Atomic Absorption Spectrophtometer) instrument analyses the gold concentration. 


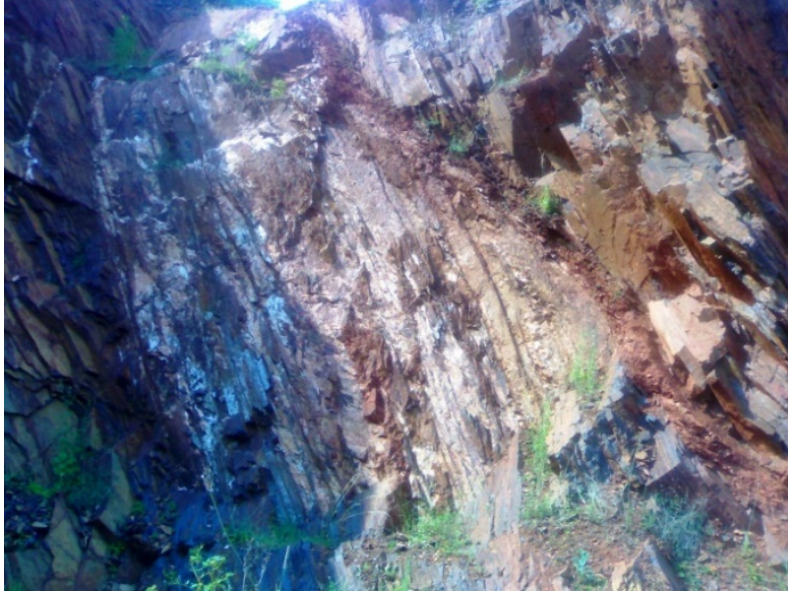

Fig. 7 BIFs with sheared quartz-vein.

\section{RESULTS AND DISCUSSIONS \\ 4.1. IDENTIFICATION OF BIFS}

The last few decades have witnessed vast developments in the area of Remote Sensing applications in various fields, including in the field of geological sciences. Remotely sensed data can be effectively used in mineral exploration, and rock identification is a part of this. Remote sensing data are preferred as large areas can be covered cost-effectively and have the advantage of studying inaccessible and rugged terrains. Also, rapid remote sensing data collection is possible at regular and frequent intervals. These developments have made it possible to identify and map different geological units and even alteration zones (Mohamed, 2021; Yi et al., 2021). Furthermore, due to rapid advances in sensor technology, remote sensing applications in the field of rock identification and, thus, in geological mapping, using spectral signatures characteristic of minerals constituting a rock or an ore have increased significantly. However, geological interpretations from remote sensing images need to be validated in the field (Roy et al., 2010).

Recent advancements have made it possible to identify different minerals through spectral remote sensing, which is helpful for mapping host rocks and even alteration assemblages (Papp and Cudahy, 2002; Kruse et al., 2003; Perry, 2004). Considering the above, remote sensing data coupled with field investigations have been employed in the present study to identify the BIFs. Remote Sensing data in the form of a Landsat-7 ETM-plus sensor is used for this purpose. The Landsat-7 ETM-plus has a total of eight bands, viz. bands 1 to 8 (https://www.usgs.gov.in), each band covering a particular part of the EM spectrum. The band-7 (2.08 - $2.35 \mu \mathrm{m})$, having a resolution of $30 \mathrm{~m}$ (Ihlen, 2019), is an essential and valuable band for discrimination of different geological rock formations, and it is also effective in identifying zones of hydrothermal alteration in rocks associated with mineral deposits

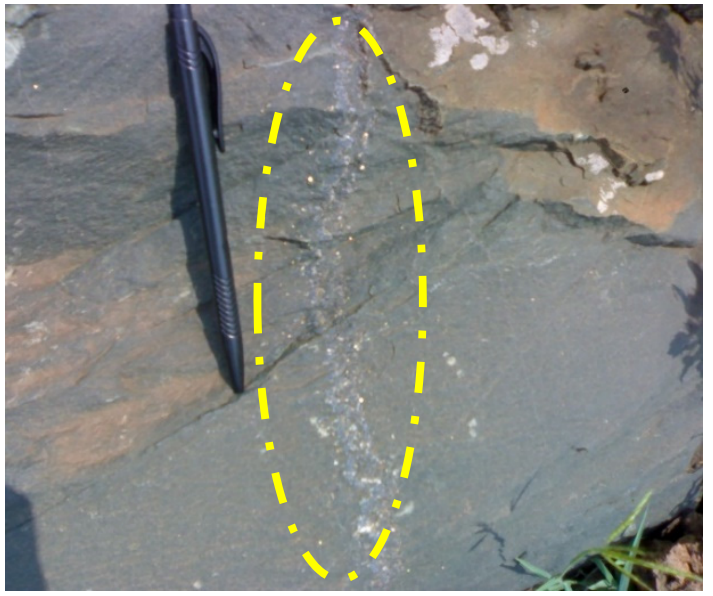

Fig. 8 An outcrop of Pyritiferous Metabasalt.

(https://www.edc.uri.edu/nrs/classes/nrs409509/RS/L ectures/2018 409509SatelliteRemoteSensing2018\%20new. pdf; https://www.usgs.gov/faqs/what-are-best-landsatspectral-bands-use-my-research?qt-

news science products $=0 \#$ qt-news science products).

To identify the BIFs in the satellite images, the ground control points (GCPs) for BIFs are used. These GCPs are used for supervised classification that uses the similar reflectance of the GCP pixels and other pixels in the image. Apart from this, the Spectral Characteristics Viewer option available on the USGS website (https://landsat.usgs.gov/spectral-characteristicsviewer) is used to view the spectral characteristics for the two iron minerals viz. haematite and goethite for the band-7 of Landsat-7 ETM+. This option demonstrated that haematite shows a higher spectral character (i.e. reflectance) than goethite. Thus, it helps identify BIF as having a component of haematite.

Once the BIFs are identified on the satellite image, their spatial locations are verified by superimposing these BIFs field locations onto the satellite image. The study is carried out using ArcGIS capabilities. Thus identified BIFs are shown in Figure 9. Again, the BIF bands are trending in the NW-SE direction.

\subsection{IDENTIFICATION OF LINEAMENTS AND SHEAR ZONES}

A lineament is a linear feature that includes structural features like fault lines, fractures, joints, shear zones and intrusives like dykes and veins. Identification of the lineaments on the satellite imageries includes multiple approaches such as visual identification aided by features like the linear alignment of natural vegetation and linearity of streams, and image processing approaches including edge enhancement and directional filtering techniques (Maina and Tudunwada, 2017), and tonal variation (Bhowmick et al., 2020). In addition, Digital Elevation Models (DEMs) are also used to identify lineaments. In the present study, lineaments including shear zones have been identified using multiple approaches, i.e., visual identification, field identification, and 


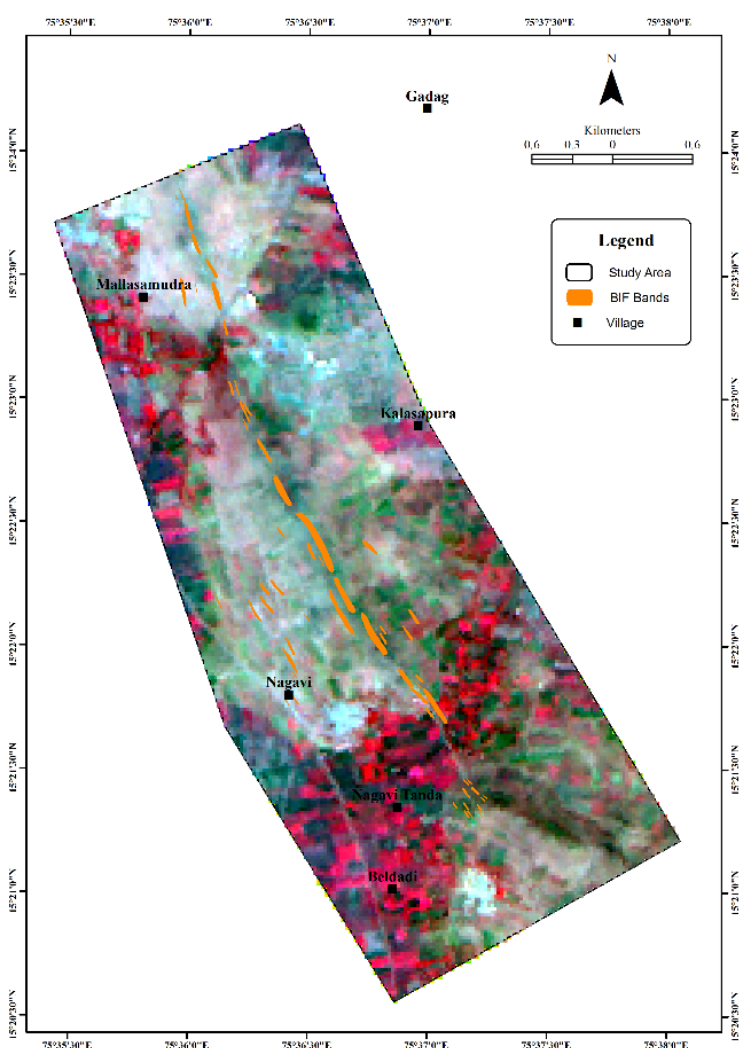

Fig. 9 BIFs identified in the Nagavi area.

identification using the Cartosat DEM. Lineaments in a digital elevation model are defined by a drop-in elevation (Wladis, 1999). A lineament is a continuous series of pixels having similar terrain values (Koike et al., 1998). Several lineaments have been identified in the Nagavi area (Fig. 10). Most of these trends are NW-SE, and they are all identified as continuous ones. Few shear zones showing gold mineralisation have also been identified in the central part of the area, as shown in Figure 10.

\subsection{BIFS, LINEAMENTS AND SHEAR ZONES IN THE NAGAVI AREA}

The BIFs, lineaments and shear zones in the Nagavi area are identified as explained above, and they are superimposed on satellite data to get a complete picture. First, the auriferous shear zones and the BIFs are superimposed on the Landsat image (Fig. 11). From this, it is clear that these shear zones occur along the BIFs, indicating their interrelationship.

Later, all the three, i.e., BIFs, shear zones and the lineaments, are superimposed on the satellite image (Fig. 12) to identify any possible effect of lineaments on the gold mineralisation. However, this superimposition of BIFs, shear zones, and lineaments does not relate between shear zones and the lineaments.

\subsection{GOLD IN THE BIFS OF NAGAVI AREA}

When forming a large deposit of a noble element like gold, the source liquid must be sufficiently

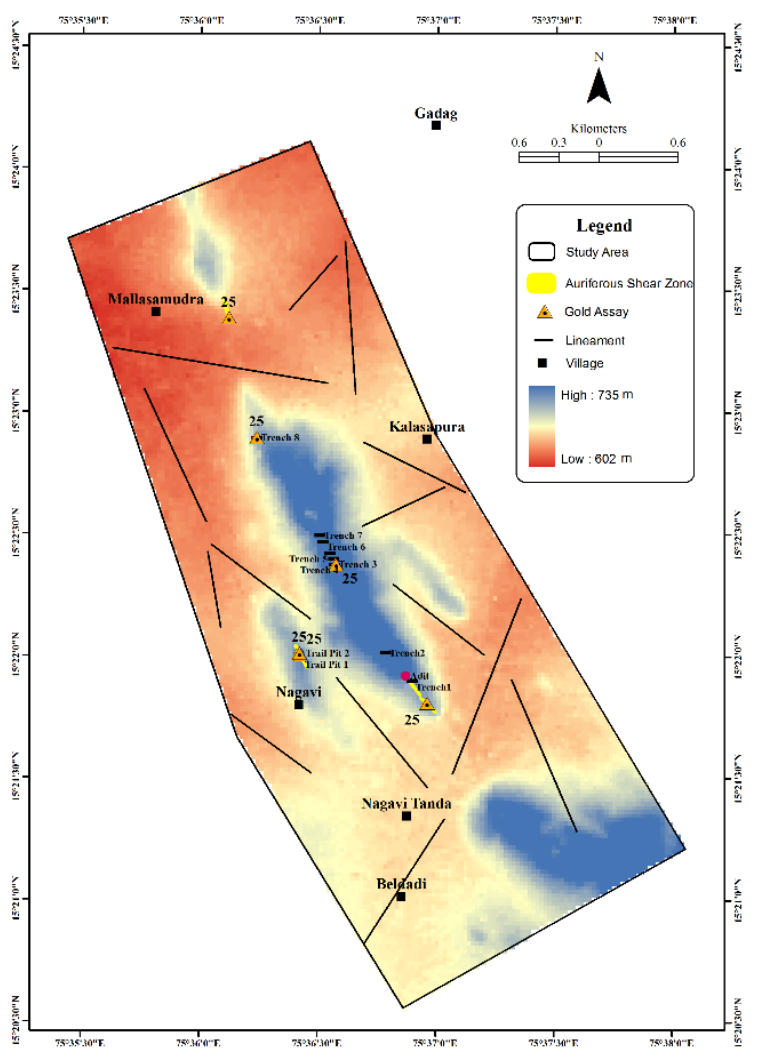

Fig. 10 Lineaments and shear zones identified in the Nagavi area.

enriched in them. Then, they are transported to the shallower subsurface from the deeper parts (Hamlyn et al., 1985). Botcharnikove et al. (2011) have shown the relation between sulphur and gold concerning the solubility and mobility of gold. Also, it is well known that sulphide minerals, especially arsenopyrite and pyrrhotite, occur along with gold. Gold is associated with sulphide, which commonly occurs as inclusions in pyrite grains, along boundaries of pyrrhotite, and in gangue minerals as micro-crack fillings in pyrite or as discrete grains. Considering this relationship between sulphur and gold, seven BIFs samples have been analysed for their sulphite $\left(\mathrm{SO}_{3}\right)$ content, and the same is presented in Table 1. The $\mathrm{SO}_{3}$ content is found to vary from 0.02 to $0.13 \%$.

Another seven samples have been analysed for their gold concentration using GTA-AAS at the Geological Survey of India laboratory, Chemical Division, Bengaluru, India (Table 2). Gold concentration in all seven samples is less than $25 \mathrm{ppb}$.

Samples NNB 14 and NNB 15 are collected from a sheared quartz vein at its contact with BIF. This quartz vein exhibits brownish colour due to the oxidation of sulphides. The quartz vein shows prominent pinching and swelling structures. Samples NNB 16 and NNB 27 have been collected from old working trial pits (trial pit 1 and trial pit 2) at different places at the contact of auriferous shear zones. Samples NNB 17 and NNB 24 are collected from old workings (trenches). The gold concentration from the samples of the Nagavi area is similar to that of those 


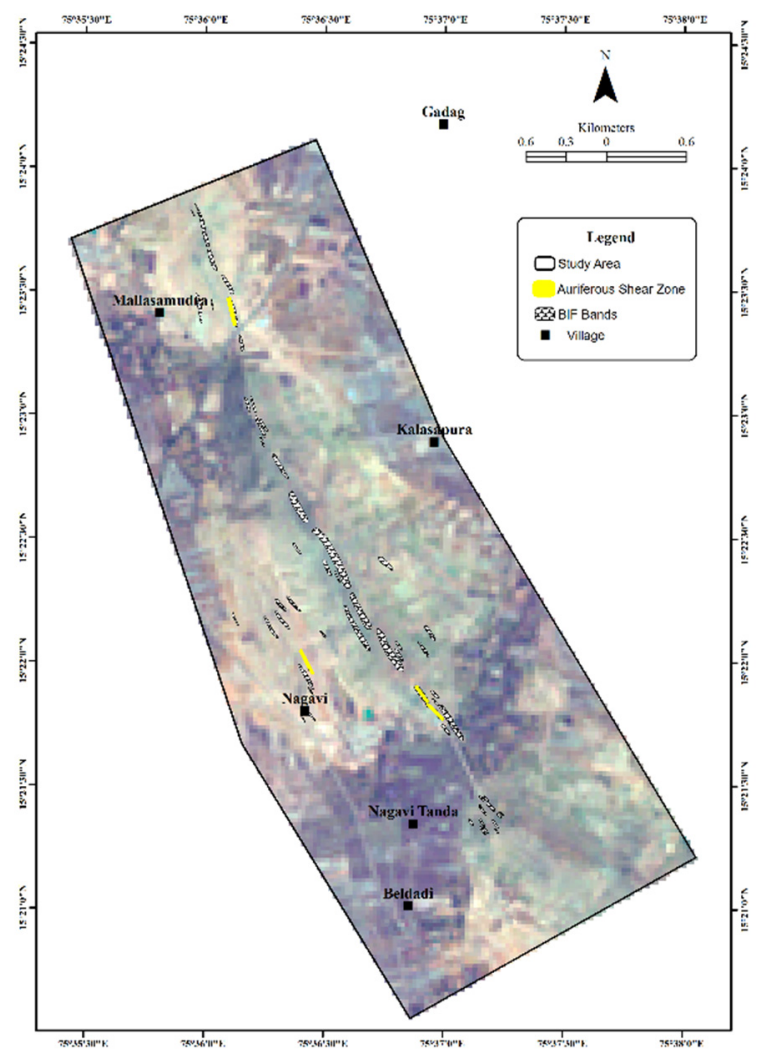

Fig. 11 BIFs and shear zones of the Nagavi area on the Landsat image.

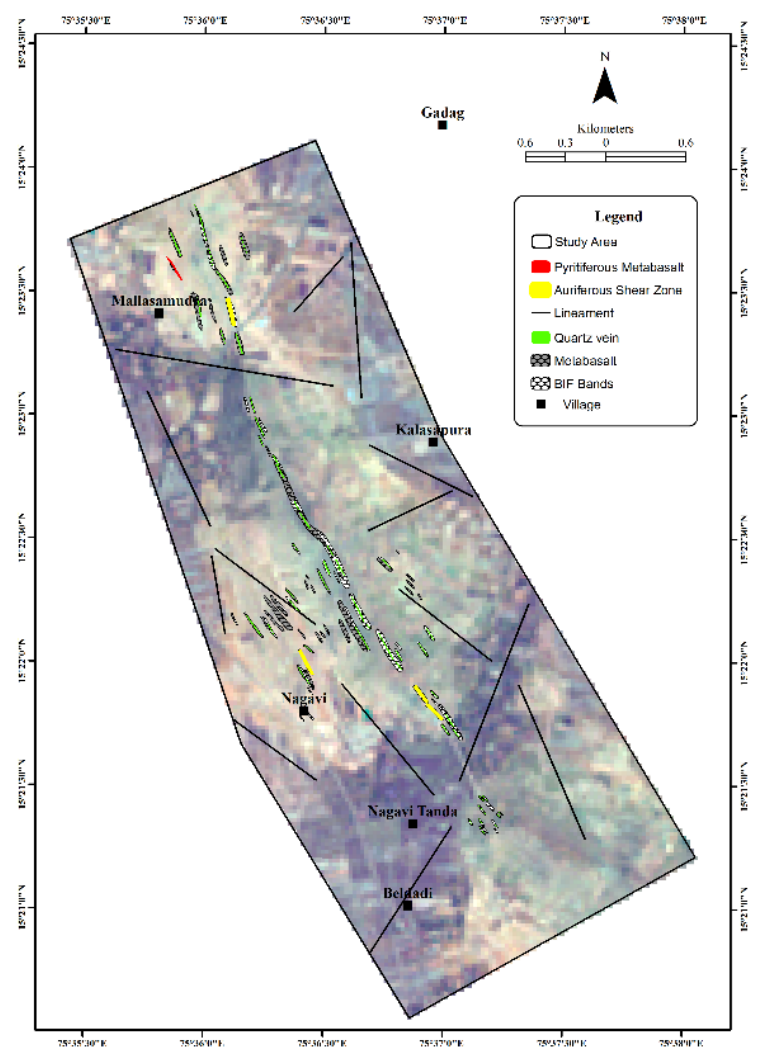

Fig. 12 BIFs, shear zones and lineaments of the Nagavi area on the Landsat image.

Table 1 Sulphite concentration in BIFs samples.

\begin{tabular}{llc}
\hline Sample No. & \multicolumn{1}{c}{ Sample description } & $\mathbf{S O}_{3}(\mathbf{\%})$ \\
\hline NNB 1 & Banded hematite chert, near Nagavi & 0.02 \\
NNB 5 & BIFs sample from an old working pit & 0.06 \\
NNB 6 & BIFs with sheared quartz vein at its contact with shale, from an old working pit & 0.03 \\
NNB11 & Reddish brown-banded magnetite chert, near Nagavi & 0.04 \\
NNB 12 & BIFs with quartz vein intrusions, near Mallasamudra & 0.05 \\
NNB18 & Banded hematite quartzite, near Nagavi & 0.13 \\
NNB 22 & Banded hematite quartzite in an old working pit & 0.07 \\
\hline
\end{tabular}

Table 2 Gold $(\mathrm{Au})$ concentration in different samples.

\begin{tabular}{llc}
\hline Sample No. & \multicolumn{1}{c}{ Description } & Au by GTA- AAS (in ppb) \\
\hline NNB 14 & Sheared quartz vein zone with BIFs contact & $<25$ \\
NNB 15 & Sheared quartz vein on top of hill & $<25$ \\
NNB 16 & Sheared auriferous zone (trial pit No.1) & $<25$ \\
NNB 17 & Ancient working (trench) & $<25$ \\
NNB 24 & Ancient working (trench) & $<25$ \\
NSB 27 & Sheared auriferous zone (trial pit No.2) & $<25$ \\
\hline
\end{tabular}

from different Archaean greenstone belts in countries such as Australia (Vielreicher et al., 1994), Canada (Lhotka and Nesbitt, 1989), South Africa (Pretorius et al., 1988) and Zimbabwe (Saager et al., 1987).

\section{CONCLUSIONS}

This study has shown that BIFs and structural features like lineaments and shear zones can be identified using an integrated approach involving remote sensing data and field investigations. Identification of linear bands of BIFs, lineaments, and shear zones can be carried out using manual identification and techniques like edge enhancement coupled with field data. This integrated study has revealed that the auriferous shear zones in the Nagavi area occur along the BIFs. Further, it is also noticed that the lineaments have probably no control over the shear zones. The gold concentration in samples collected from sheared quartz veins, sheared zones, and ancient workings is less than $25 \mathrm{ppb}$ and conforms with similar geological terrains from other countries. 


\section{REFERENCES}

Abdullah, A., Nassr, S. and Ghaleeb, A.: 2013, Remote sensing and geographic information system for fault segments mapping a study from Taiz area, Yemen. J.. Geol. Res., 201757. DOI:10.1155/2013/201757

Bhowmick, A., Ojha, J.R., Chaturvedi, S.K., Singh, C.K. and Seyoum, T.: 2020, Detection and interpretation of lineaments using remote sensing and GIS techniques in Amessa Guracha watershed of the Main Ethiopian Rift valley, East Africa. Int. J. Sci. Technol. Res., 9, 4, 2286-2291.

Botcharnikov, R., Linnen, R., Wilke, M., Holtz, F., Jugo, P. J. and Berndt, J.: 2011, High gold concentrations in sulphide-bearing magma under oxidising conditions. Nature Geosci., 4, 112-115. DOI: 10.1038/ngeo1042

Ciampalini, A., Garfagnoli, F., Del Ventisette, C. and Moretti, S.: 2013b, Potential use of remote sensing techniques for exploration of iron deposits in western Sahara and southwest of Algeria. Nat. Resour. Res., 22, 179-190. DOI: 10.1007/s11053-013-9209-5

Feizi, F. and Mansouri, E.: 2013, Introducing the iron potential zones using remote sensing studies in south of Qom province, Iran. Open J. Geol., 3, 4. DOI: $10.4236 /$ ojg.2013.34032

Hamlyn, P.R., Keays, R.R., Cameron, W.E., Crawford, A.J. and Waldron, H.M.: 1985, Precious metals in magnesian low-Ti Lavas: Implications for metallogenesis and sulfur saturation in primary magmas. Geochim. Cosmochim. Acta, 49, 8, 17971811. DOI: 10.1016/0016-7037(85)90150-4

Koike, K., Nagano, S. and Kawaba, K.: 1998, Construction and analysis of interpreted fracture planes through combination of satellite-image derived lineaments and digital elevation model data. Comput. Geosci., 24, 6, 573-583. DOI: 10.1016/S0098-3004(98)00021-1

Kruse, F.A., Bordman, J.W. and Huntington, J.F.: 2003, Comparison of airborne hyperspectral data and EO-1 Hyperion for mineral mapping, IEEE Trans. Geosci. Remote Sens., 41, 6, 1388-1400. DOI: $10.1109 /$ TGRS.2003.812908

Lhotka, P.G. and Nesbitt, B.E: 1989, Geology of unmineralised and gold-bearing iron formation, Contwoyto Lake - Point Lake region, Northwest Territories, Canada. Can. J. Earth. Sci., 26, 46-64.

Maina M.M. and Tudunwada, I.Y.: 2017, Lineament mapping for groundwater exploration in Kano state, Nigeria. Int. J. Adv. Agric. Environ. Eng., 4, 1, 226229. DOI: 10.15242/IJAAEE.AE0517241

Mandeng, E.P.B., Bidjeck, L.M.B., Wambo, J.D.T., Taku, A., Betsi, T.B., Ipan, A.S., Nfada, L.T. and Dieudonné, L.B.: 2018, Lithologic and structural mapping of the Abiete-Toko gold district in southern Cameroon, using Landsat 7 ETM+/SRTM. C.R. Geosci., 350, 3, 130-140. DOI: 10.1016/j.crte.2017.11.003

Mao, Y., Wang, D., Liu, S., Song, L., Wang, Y. and Zhao, Z.: 2019, Research and verification of a remote sensing BIF model based on spectral reflectance characteristics. J. Indian Soc. Remote Sens., 47, 10511061. DOI: $10.1007 / \mathrm{s} 12524-019-00965-\mathrm{z}$

Mohamed, M.T.A., Al-Naimi, L.S., Mgbeojedo, T.I. and Agoha, C.C.: 2021, Geological mapping and mineral prospectivity using remote sensing and GIS in parts of Hamissana, northeast Sudan. J. Pet. Explor. Prod. Technol., 11, 1123-1138.

DOI: $10.1007 / \mathrm{s} 13202-021-01115-3$
Moretti, S. and Righini, G.: 2013a, Remote sensing techniques using Landsat ETM + applied to the detection of Iron ore deposits in western Africa. Arab. J. Geosci., 6, 1, 4529-4546. DOI: $10.1007 / \mathrm{s} 12517-012-0725-0$

Naqvi, S.M. and Rana Prathap, J.G.: 2007, Geochemistry of adakites from Neoarchean active continental margin of Shimoga schist belt, Western Dharwar Craton, India: implications for the genesis of TTG. Precambrian Res., 156, 32-54.

Naqvi, S.M. and Rogers, J.J.W.: 1987, Precambrian Geology of India: Oxford Monographs on Geology and Geophysics, No. 6, Oxford University Press, New York, $223 \mathrm{pp}$.

Naqvi, S.M.: 2005, Geology and evolution of the Indian plate (From Hadean to Holocene $4 \mathrm{Ga}$ to $4 \mathrm{Ka}$ ). Capital Publishing Company, New Delhi, 450 pp.

Papp, E. and Cudahy, T.: 2002, Hyperspectral remote sensing, geophysical and remote sensing methods for regolith exploration. E. Papp, ed., CRCLEME Open File Report 144, 13-21.

Perry, S.L.: 2004, Spaceborne and airborne remote sensing systems for mineral exploration - Case histories using infrared spectroscopy. Infrared Spectroscopy in Geochemistry, Exploration Geochemistry, and Remote Sensing (P.L. King, M.S. Ramsey, and G.A. Swayze, eds.), Mineralogical Association of Canada, 227-240.

Pretorius, A.I., van Reenen, D.D, and Barton, J.M.Jr.: 1988, BIF-hosted gold mineralisation at the Fumani Mine, Sutherland G.reenstone belt, South Africa. S. Afr. J. Geol., 91, 4, 429-438.

Rajamani, V., Shivakumar, K., Shirey, S.B. and Hanson, G.N.: 1985, Geochemistry and petrogenesis of amphibolites from the Kolar Schist Belt, South India: evidence for ultramafic magma generation by low percent melting. J. Petrol., 26, 92-123.

Roy, P.S., Dwivedi, R.S. and Vijayan, D. (eds.).: 2010 , Remote Sensing Applications. National Remote Sensing Centre/Indian Space Research Organization, NRSC/ISRO.

Saager, R., Oberthür, T. and Tomschi, H.: 1987, Geochemistry and mineralogy of banded ironformation-hosted gold mineralisation in the Gwanda Greenstone Belt, Zimbabwe. Econ. Geol., 82, 2017 2032. DOI: 10.2113 /gsecongeo.82.8.2017

Sawkar, R.H.: 2010, Gold Mining, A development authority in Karnataka, J. Geol. Soc. India, 76, 208-214. DOI: $10.1007 / \mathrm{s} 12594-010-0102-0$

Vielreicher, R.M., Groves, D.I., Ridley, N.J. and McNaughton, N.J.: 1994, A replacement origin for the BIF-hosted gold deposit at Mt. Morgans, Yilgarn Block, W.A. Ore Geol. Rev., 9, 4, 325-347. DOI: 10.1016/0169-1368(94)90003-5

Wladis, D.: 1999, Automatic lineament detection using digital Elevation models with second derivative filters. Photogramm. Eng. Remote Sens., 65, 4, 453-458.

Yi, L., Changbao, Y. and Zhiguo, M.: 2021, Lithology discrimination using Sentinel-1 Dual-Pol data and SRTM data. Remote Sens., 13, 7. DOI: $10.3390 /$ rs 13071280 